\title{
Toward Enhancing Police-Community Relations in Nigeria: Problems and Prospects
}

\author{
Maikano Madaki, Ph.D \\ Department of Sociology, Bayero University, Kano- Nigeria \\ E-mail: madakiabdul@yahoo.com \\ Mustapha Hashim Kurfi \\ Department of Sociology, Boston University, Massachusetts- U.S.A \\ E-mail: mustapha@bu.edu
}

Accepted: June 03, 2013 Published: July 09, 2013

Doi:10.5296/jsr.v4i2.3972 URL: http://dx.doi.org/10.5296/jsr.v4i2.3972

\begin{abstract}
This paper examines the existing relationship between the police and members of the public in Nigeria, highlighting the various problems endemic in both parties (the police and the public). The paper provides the essential pragmatic means of further enhancing this relationship for a better and peaceful society through the principles of community policing. The authors take a multi-dimensional approach to the police public relationship (P-PR) in Nigeria positing thatprimarily, there are structural, organizational, and attitudinal factors that led to the deteriorating nature of the P-PR in Nigeria. The paper posits that co-operation between the police and the public is a prerequisite for the success of any law enforcement agency, notably the police as well as a better, peaceful, and harmonious society. The police alone cannot achieve this without support from the members of the public whom they serve. For that kind of good working condition to be created, the police need to be polite, friendly, approachable, honest, law abiding and demonstrate high sense of responsibility in dealing with members of the public and in discharging their duties. On the other hand, the public must understand that maintaining law and order is a collective responsibility between the parties and should do everything possible to assist the police in protecting lives and property. Good and objective partnership between the community and the police will help bring positive response to crimes and other social problems. This can be achieved by ensuring proper and genuine police reform in the country to overhaul the organization and by bringing to book corrupt officers and men as general and specific deterrence.
\end{abstract}

Key Words: Police, Public, Relationship, Community policing, Corruption, Boko Haram, Trust

\section{INTRODUCTION}

The police, as law enforcement agents, have existed for a very long time in the world and specifically Nigeria. Notwithstanding, even before the emergence of the conventional 
formal police in the country, different regions have had some semi-formal institutions that were carrying out the work of the police. During the colonial era, the police were operating in a more decentralized setting which allowed for regional security officers that are charged with the responsibility of maintaining law and order. In 1966, these local regional forces were dissolved by the government of General Yakubu Gowon, and the central police institution was established. The police are the biggest, most visible and most important sub-system of the criminal justice system. They provide the entry points into the system either through crime reports from the public or its own discovery. It is the main institution that provides regular direct contact with the public (Dambazau, 1999). Moreover, the Nigeria Police Force (NPF) has the role of upholding the law, safeguarding justice and protecting the lives, rights and dignity of its citizens and visitors. The police cannot achieve this task without support from the members of the public. As such, they have the community as their primary level of interaction which requires good relationship with the public for effective service delivery. This paper examines the existing relationship between the police and members of the public in Nigeria, highlighting the factors that led to the current situation, and suggesting pragmatic ways to further enhance cordial relationship for a harmonious and more peaceful society.Before examining the police-public relationship (P-PR) it will be appropriate to highlight the roles and responsibilities of the Nigerian police force (NPF).

\section{The Nigerian Police Force: Roles and Responsibilities}

The cardinal principles of establishing the Nigeria Police Force is to maintain law and order as well as safeguard and protect lives and property of all citizens of the country. To achieve this, section 194 (1) of the 1979 Constitution of the Federal Republic of Nigeria and subsequently the 1999 Constitution of the country provides that the Nigeria Police Force (NPF) shall have such powers and duties as conferred upon them by law. The police refer to a particular kind of social institution, while policing implies a set of processes with specific social functions. The police are the main institution that provides regular direct contact with the public, a situation that makes it unique among other law enforcement agencies and agents. The job of the police is so complex and enormous to the extent that they supervised through patrol the activities of the societal members in order to ensure effective policing. Policing is a process that involves detection and punishment of wrong acts as negative re-enforcement to criminal behavior and deters potential wrong doers. It is an aspect of social control process involving surveillance and sanctions intended towards ensuring security of the whole (Maguire, Morgan and Reiner, 1997). In essence, Reiss (1971) explains that policing involves a situation whereby the police mediate between the community and the legal system. Notwithstanding, Quincy (1979) posited that the police are by nature disliked by the public due to the somewhat intrusive nature of their jobs.

Johnson and Gregory (1971) highlight the roles and responsibilities of the police, arguing that unlike many other occupational roles, the policeman's role is ambiguous. $\mathrm{S} / \mathrm{he}$ is a friend and a protector. S/he assures safety on the streets and keeps the peace. You call $\mathrm{him} / \mathrm{her}$ when you are in trouble, when your neighbors are making too much noise, or when your property is lost. At the same time, this police man/woman is a foe and a repressor. $\mathrm{S} / \mathrm{he}$ inhibits your freedom; charges you when you violate a law, or illegally parked; comes to your 
house to quiet you down when your neighbors complain about noise; investigates; and interrogates you when you are suspected of or involved in some illegal activity. Although, the above scenario reflects what is obtained in American society couple of decades ago, it is exactly the situation in Nigeria and perhaps elsewhere. Fundamentally, Johnson and Gregory (1971) describe the police work as particularly dynamic, complex, delicate yet important, and this applies to every existing human society. Buttressing the above point, Black (1968) explained the ramifications and complications of police work, asserting that the policeare responsible for protecting life and property, preventing lawlessness, and apprehending law breakers. A police is imagined as chasing hardened criminals, capturing bank robbers, and investigating murders. Similarly, Goldsmith and Harris (2012) believe that considering the nature of police work, obtaining cooperation can be particularly difficult. Despite that, policing, like many other activities, benefits from cooperation and collaboration with other partners, notably the public.

In line with the above therefore, the public need to appreciate the fact that their maximum support is a necessity for the success of safeguarding the lives and property of the whole and for a better and sustainable development. Gourley (1954) argues that the police and the public are in a sense identical and that the police represent only a small fraction of the public they serve. Additionally, he asserts that citizens cannot discard their responsibility to police themselves merely by retaining professional police to perform the daily tasks for which citizens have no time, the capacity, and the inclination. Thence, the police can never adequately discharge their obligations to protect life and property unless they are reinforced by the good will and cooperation of the public. Although, Gourley's audience was the mid-20thcentury Americans, his message is clear and applicable to the Nigerian public of the 21 stcentury and beyond. The citizens must understand that their security and welfare are, to a great extent, dependent upon the maintenance of an orderly society, which in turn is dependent upon the effectiveness and efficiency as well as the prestige of the police.

According to Fielding (1996) cited in Wright (2002), there are three models that characterize policing work. These include:

i. The enforcement model, which largely focus on the police work ofcrime control and law enforcement.

ii. The service model that set policing priorities for dealing with crime control, order maintenance and service delivery in consultations with the public.

iii. The community model, which gives priority to maintaining public tranquility over crime control. The philosophy here is that the police and the public have the responsibility for keeping their society safe in order to ensure security of lives and property.

The police are responsible for enforcing all criminal laws irrespective of whether citizens wish to be policed or not. According to Alemika (1993), the police force is created to primarily promote harmony and security of lives and property in the society. However, what 
is important is how the police conduct themselves in the process of discharging their legal function, which is always the problem in Nigeria. Further, Ehindaro (2005) observed that the police alone cannot combat crime without co-operation from the public. Without strong ties with the community, the police may not have access to vital information from the citizens that could help control, manage, solve and deter crime.How then do the NPF relate to the public? How is the current relationship? What are the factors responsible for the current situation? How ought the ideal relationship?

\section{The Police-Public Relationship in Nigeria: Explication and Examination}

The relationship between the police and members of the Nigerian public is very important in the sense that the former can only succeed in discharging responsibilities when there is good and cordial working relationship with the later. It is only through cordial relationship between the two, the police can be able to play their roles as expected thereby recording tremendous success in terms of providing security to lives and property. The police are supposed to be polite, obedient, law abiding, intelligent, calm, and educated for them to be able to perform up to expectation. But in Nigeria, members of the public always see the police with disdain and disrespect because of bad attitudes. The public mostlydislike theNPF because they(the police)are parading themselves as unfriendly beggars, money extorters, intimidators, and so on (particularly to the underprivileged), and as such, the public do not have confidence in them. White, et al (1991) explained that the relationship between the police and members of the public in Nigeria have tended to be characterized by deep-rooted conflict, prejudice, corruption, and violence. In the same line of thought, findings of Hills (2008) revealed that despite decades of police assistance and the recent introduction of reform plans, Nigeria's public police remain notoriously brutal and corrupt. She attributes that to many factors including a challenging environment; under-resourced officers incapable of effectively policing the most populous poverty-stricken Black nation on earth;high rates of urbanization and a volatile underclass of unemployed youths; the lack of social cohesion and traditional control mechanisms; insufficient thought to public order strategy; unlawful arrests and detention; slow response of the police during widespread rioting; and excessive use of discriminate force. By implication therefore, several factors are in play.

Nevertheless, most of these police unfriendly and unconventional attitudes may be as a result of the internal problems they are having as an organization. Ideally, the police supposed to be provided with all the necessary good working condition and tools, equipment, facilities and professional training for them to effectively render the service. The minimum welfare package (these include timely promotion, good remuneration, housing, transport, health care services and so on) need to be provided to the police. This will make them comfortable and go a long way in making them behave themselves. But the reverse is almost, if not, the case in Nigeria.

Woods (1979) believed that daily, the police and the public meet each other in a series of events and whenever they meet either live satisfied and happy with each other or disappointed and angry with each other and these may positively or negatively affect the way the public and the police perceive each other. Some scholars like Brown (1970) maintain that the role of the police in a democratic society is to be more tolerant of their diverse clientele 
(community members), build trust between officers and citizens, improve community relations and invest more resources in crime prevention. Bunyard (1978) explain that the police and the public have a relationship that is circular in nature. He stated that if the public help the police, the police can be effective, and if the police are effective, the public will feel secure and they will be willing to help the police. He further added that if one link is broken, the whole arrangement will be broken. As such, for the police to be effective and tackle crime within the community; the community must help the police, and it is only through this relationship that community policing can be possible and successful. In categorical terms, what are the main problems in the existing relationship between the police and the public?

It is worthy to note that from the onset, our understanding of, and approach to the police-public relationship in Nigeria is multidimensional. Broadly, we view the problems of the police-public relationship from: the Nigerian social structure; the organizational structure of the police; and the worldviews of the police and the public.

Reiner (2000) asserts that the police are often in conflict with a significant percentage of the population, and that this phenomenon is found in almost every country of the world. This, he attributes to the fact that the police are agencies of the state that are employed to maintain law and social order, which serve the interest of the ruling class. As a result, maintaining neutrality is utopian. Alemika (1999) argues that, it is the police's partiality in favor of the state interest, and at the detriment of the majority of the population that inevitably creates hostile relationship with their host communities that they "serve" across countries. Thus, if the police will be used by the state as coercive mechanism in rigging elections, disorganizing lawful assemblies including protests and peaceful demonstrations, unlawful arrests, and detentions, shooting and engaging in extra-judicial killings, then the public will never trust the police. The current state of insecurity in northern Nigeria that is linked to the activities of Jama'atu Ahlus Sunnah lid Da'wati wal Jihad nicknamed Boko Haram (Western education is forbidden)-a Muslim militant group grew to the present situation due to the operations of the Joint Military Taskforce (JTF) which comprises of the police and others. It was, and still remains evident that the taskforce engaged in extra-judicial killings of not only the members of the militant sect but equally accused and in many instances innocent members of the public. This essentially violates the principles of law enforcement work and further denies the known rule that a suspect remains innocent until found guilty through legal procedures.

In line with the above, Kunle Shitu (2013) argues that there is no way one can justify the extra-judicial killing of the Boko Haram leader, Muhammad Yusuf, who was apprehended with no arm at his disposal, paraded for press conference, and then killed without trial. Amazingly "interesting," the security operatives, not only denied the killing, but equally went further to kill many people in the name of Boko Haram. As a matter of fact, the residents of Maiduguri and Yobe states, the home-base for the Boko Haram confirm that the JTF have killed more than the militant sect as is evident in Ra'ayi Riga- a bbchausa phoning-in program of October $12^{\text {th }}, 2012$.

Corruption is a major factor that plays out in the bad P-PR. Nigeria has a widespread reputation for corruption. In 2000, it appeared at the top of Transparency International's list of the most corrupt countries, and it continues to be regarded as a bastion of fraud, graft, and 
deceit (Transparency International, 2009; Smith, 2010). In Nigeria today, the problems of development are not necessarily due to the scarcity of the natural factors of production but due to corruption which has eaten deep into the fabric of Nigerian society, and at present, one of the greatest obstacles to national development (Abdullahi 2002:9). In the language of cause and effect, corruption is often portrayed as an independent variable inhibiting the desired and supposedly dependent outcomes of democracy and development, including improving health outcomes (Transparency International, 2006).

Findings of Hills (2008) confirmed that corruption is endemic at every level, with the police regularly heading the Transparency International's list of the most corrupt institutions in Nigeria. An average police man in Nigeria is exploited right from his/her recruitment. S/he might not be the best fit for the job, but paying-off can get him there. At the police training colleges, the quality and quantity of food they are served is nothing to write home about; the allowances are not assured of being fully paid and as at when due; during passing-out bribes may be given for a "better" posting; before and upon arriving at respective areas of primary assignment may attract a continuation of the trend; and even "returns" might be solicited to the senior ranking officers. At retirement, no one can guarantee that entitlements will be given without giving out bribes. In the event a police officer dies while in service, the so-called "commissioner's regret allowance" is not enough for the deceased officers' family to sustain a living for the period of mourning; needless say there's a befitting burial, if the deceased's culture permits. These frustrations usually contribute to the increased corrupt practices of the police- something that is in the fabrics of the police, at the best in the public's eyes.

There are government efforts to reform the Nigerian police and especially during the late Umaru 'YarAdua. But why do the policepersist in the corrupt practices? Part of the answer to that will be that; even those that are found guilty in siphoning public funds, including the police pension scam under Maina's Committee and the over celebrated case of Alaimaseayaare not given proper attention and neither are they accorded the legally needed concern. In other words, the Nigerian leaders in most cases never acts their words as the two seem to differ when it come to practical realities of life. Good policies are made regarding prevention and control of corrupt practices in the country, but actions are not properly and promptly taken because the key players of the criminal justice system (the police and the judiciary) are very corrupt.

In line with the above and by implication therefore, unless and until there are trust, confidence, and cooperation, the current deteriorating relationship between the police and the public in Nigeria will continue and reverting to smooth relationship will certainly be in vain.Having identified the necessity for a cordial relationship between the parties involved, this lays the foundation for the prospect which is community policing.

\section{Way Forward: Community Policing}

The concept of community policing emerged in an attempt to bridge the gap and distance between the police and the public in order for them to work together in policing their immediate communities. The idea was to integrate the police into the local communities in a 
kind symbiotic relationship with the aim of reducing crime thereby enhancing peaceful co-existence. According Davies (2006), community policing is a way conducting oneself in a professional way as a security personnel. It is the foundation for successful structural and operational police administration.

In order to enhance the relationship between the police and members of the public, there need to be a shift from the present day system of intimidation through "police force" to the modern system of policing through "police service". While the entire Nigeria Police require total and complete attitudinal change for them to regain people's confidence, the principles of the new world paradigm of policing - community policing - supposed to be their guide for a better society. Community policing is a system of policing that allow members of the public to be part and parcel of policing their community. It provides the platform upon which the criminal justice system (including enforcement, prosecution, courts and prisons) could begin to function as a scam less whole, with all the elements working as partners with the people who have the most gain or loss in making their communities better and safer. In other words, the police move away from their traditional approach centered on crime fighting and started finding ways to look toward the community and solve problems from their roots.

Community policing recommends good working relationship between the police and members in the sense that they collectively recognize specific problems facing the community and collaborate to solve them. That is, the police are no longer the sole guardians of law and order, rather, community members are allies who work together to improve safety in the community. This kind of policing is characterized by the notion "police service" and not "police force", where the most significant bench marks of performance are public satisfaction, trust and confidence. This is one of the reasons why in the United States, there is a special department under the Ministry of Justice called COPS (Community Oriented Police Service) and the police are also called COPS. The take-home from this name is that ideally, the police are a community-oriented service and not a force as the case in Nigeria. According to Brodgen and Nijhar (2005), community policing is based on the premise that a strong partnership between the police and the citizens will help increase public safety and reduce crime. This policy has proved to be effective in the US, Japan, and China. Nigeria also started practicing its principles in 2004. The essence is to focus on constructive engagement with people who are the end users of the police service and re-negotiate the contract between the people and the police thereby making the community co-producers of justice and a quality police service (Yusuf, 2007).

The community policing (as a police service philosophy) has some fundamental principles, these include:

- Practice policing by consent not coercion

- Be part of the community not part from it

- Find out (together with the community) what the community needs

- Work in partnership with other agencies and the public

- Tailor the business of policing to meet the community needs

- Be accountable for its service

- Provide a quality service 
- The Police adopt a proactive problem solving approach to their roles and responsibilities(Yusuf, 2007).

In addition, other core values of the Nigeria Community Policing Model include the following:

- Respect and protect human rights

- Be transparent and open in their policing function

- Demonstrate commitment at all times to deliver best quality services

- Empower police personnel through training and re-training for effective service delivery

- Be willing to seek, listen to and act upon public opinion and perception

- Be accountable and properly answerable for what they do

- Ensure that citizens with a genuine sense of grievances against the police have effective redress(DFID, 2005).

Furthermore, community policing is anchored on a symbolic relationship between the police and the entire citizenry through which helpful information will be coming from the community members when police have established a relationship of trust and confidence with the community they serve. The community policing offers a way for the police and the community to work together to resolve problems that exists in the community (Okiro 2007). It is simply a form of policing that aims at creating a platform by which the police and the public can work together with the main aim of preventing the occurrence of crime, and helping towards a more efficient reaction to the commission of offences or crime by the police.

\section{Conclusion}

In conclusion, as Okereke (1993) rightly argues, if there is one ingredient necessary for effective law enforcement and order maintenance, without doubt, it is full public cooperation with the police. Nevertheless, Okereke further cautions that this public cooperation with the police is not given; it has to be earned. Strikingly, earning as well as retaining positive public image requires the police to, as a matter of necessity place the general public's interest as the ultimate and paramount. This has to be evident in eventually all decisions that affect the public. While it is important for the police to work together and very closely with members of the public, it is also imperative for them to be friendly, polite, honest, corruption-free, patient, law abiding, and exhibit high sense of responsibility in discharging their duties. Conversely, members of the public must understand that it is not only the responsibility of the police and other law enforcements to protect lives and property; rather, it is a collective responsibility. As Becker (1996) rightly argues, the police-community relations require a total orientation and a reciprocal dialogue that embraces the entire community. Viewed in this light then, PCR includes every contact, formal and informal, that occurs between the police department and the citizens of a community.

Finally, government must ensure that whoever violates the societal rules must be brought to book so that it will serve as deterrence to those punished and to potential violators; otherwise, police officers and other related organizations will continue to be corrupt.Proper 
and genuine police reform needs to be ensured in order to regain public confidence, and members of the public alsorequire re-orientation particularly toward positive feedback to the police. These would create the platform upon which good relationship between the parties can be settled thereby producing a better, harmonious, and peaceful society.

\section{References}

Abdullahi, A. (2002). "Corruption: The Greatest Obstacle to National Development." Nigeria: Corruption in Development. Zaria: Ahmadu Bello University.

Anderson, J. (1979). Theoretical Considerations of Offender and Obscenity in Formal Contacts with Citizens: Police Deviance. Boston: Anderson Publishing Company.

Alemika, E. E. (1993). "Police-Community Violence in Nigeria": A paper presented in a workshop, Jos, Nigeria.

Alemika, E. E. (1999). "Police-Community Relations in Nigeria: What Went Wrong?" in I. Chukwuma and I. Ifowodo (eds.) Policing a Democracy. Lagos: Center for Law Enforcement.

Bunyard, A. (1978). Toward a Conceptual Framework of Evaluating Community Policing. England: Anderson Publishing.

Black, A. (1968). The People and the Police. New York: McGraw-Hill Book Company.

Block, P. and Specth, D. (1973). Law Enforcement in a Time of Community Policing. Canada: Kelly Publishing Limited.

Brodgen, M. and Nijhar, P. (2005).Community Policing: National and International Models and Approaches, USA: Willan Publishing.

Dambazau, A. B. (1999). Criminology and Criminal Justice. Ibadan: Spectrum Books Limited

Department For Information and Development (DFID) Report, 2005.

Devies, B. (2006).Police Advisor to the Community Policing Project.

Donald Becker (1996). "Police Community Relations: A Review",in the Journal of Criminal Law and Criminology, Vol.77, No. 4.

Ehindaro, S. (2005). "Crime Indices in Nigeria: linkages to Socio-Economic Inadequacies". Being a paper presented at the National Summit in Social Security held at Abuja, Nigeria.

Goldsmith, A. and Harris, V. (2012)."Trust, Trustworthiness and Trust-building in International Policing Missions.'In Australian and New Zealand Journal of Criminology, Vol.45, No.23.

Hills, A. (2008). “The Dialectic of Police Reform in Nigeria.”In Journal of Modern African Studies, Vol.46, No.2. Cambridge: University Press. 
Johnson Deborah and Gregory Robert J. (1971). "Police-Community Relations in the United States: A Review of Recent Literature and Projects." In The Journal of Criminal Law, Criminology, and Police Science, Vol. 62, No. 1.

Maguire, Morgan and Reiner(1997).Outsider Studies in the Sociology of Deviance. New York: New York Free Press.

National Crime Prevention Council (2007): Improving Police-Community Relations through Community Policing. Bureau of Justice Assistance (2007).

Okereke, G. O. "Public Attitudes towards the Police Force in Nigeria." In Police Studies: International Review. Police Development, 113:16.

Okiro, M. M. (2007). "The Nigeria Police Force Operational Handbook on Community Policing". Ibadan: Ibadan University Press.

Reiner, R. (2000). The Politics in the Police.Oxford University Press.

Reiss, R. (1971). Criminal Justice Cultures: Bail and Remand: Contemporary Issues in Criminology. Wales: University of Wales Press.

Smith, D.J. (2010).“Corruption, NGOs, and Development in Nigeria."Third World Quarterly, Vol. 31, No.2, 243-258. Routledge: Taylor and Francis.

Quincy, R. (1979). "Community Policing in Small Towns and Rural America": Journal on Crime and Delinquency, vol. 40 no. 3. PP. 371-383.

The 1979 Constitution of the Federal Republic of Nigeria.

The Transparency International Report, 2009http://www.transparency.org/

The Blue Print Newspaper, April 1, 2013, also available online via: http://blueprintng.com/2013/04/extra-judicial-killing-of-boko-haram-leader-cant-be-justified/

White, M. F. et al (1991). The Theoretical Considerations of Officer Profanity and Obscenity in Formal Contacts with Citizens, in T. Barker and D. L. Carter (eds.). Police Deviance.Cincinnati, Ohio: Anderson Publishing Co.

Wright, A. (2002). Policing: An Introduction to Concepts and Practice. Devon: Willan Publishing.

Yusuf, A. (2007). “The Nigeria Police Force Operational Handbook on Community Policing”. Ibadan: Ibadan University Press. 